\title{
Etika Advokasi Public Relations dalam Manajemen Krisis Reputasi
}

\author{
Heni Indrayani \\ Mahasiswa Magister Ilmu Komunikasi Angkatan VII \\ he_ney@yahoo.com
}

\begin{abstract}
In handling the crisis company, Public Relations Proffesionals is required to balance the interests of companies and term of public interests. Public Relations Proffesionals often perform persuasion what course for sake of good company reputation. Here, ethics advocacy present into solutions dilematik between defending the interests of company and the public interests. In communicating to the public, Public Relations Proffesionals rests on a truth value, honesty, social responsibility, openness, loyalty, fair thinking, respect, integrity and communication frankly. The models of ethics in overcoming the crisis include Attorney Adversary Model, Two-way symmetrical model, Social Responsibility Model, Partisan versus Mutual Values Model, and Professional Responsibility Model. While ethical action Professional Public Relations in crisis management adhering to the code of professional conduct and codes of conduct to be able to behave or act as professionals in decisionmaking, and what procedures are done objectively, and be accountable.
\end{abstract}

Keywords : Professional Public Relations, Advocacy ethics, Crisis Management

\section{Pendahuluan}

Public Relations sebagai salah satu bentuk kegiatan komunikasi memiliki peran penting dalam dunia bisnis. Keberadaan Public Relations memudahkan suatu perusahaan untuk berkomunikasi dengan stakeholdernya, baik stakeholder internal maupun stakeholder eksternal. Dengan melalui berbagai kegiatan Public Relations dapat mencapai tujuan perusahaan yaitu menciptakan serta mempertahankan citra dan reputasi perusahaan di mata publik. International Public Relations Associations (IPRA) mendefinisikan Public Relations sebagai fungsimanajemen dariciriyang terencana dan berkelanjutan melalui organisasi dan lembaga swasta atau publik (umum) untuk memperoleh pengertian, simpati dan dukungan dari mereka yang terkait atau mungkin ada hubungannya dengan penelitian opini publik di antara mereka. Untuk mengaitkannya sedapat mungkin kebijaksanaan dan prosedur yang mereka pakai untuk melakukan hal itu direncanakan dan disebarkanlah informasi yang lebih produktif dan pemenuhan keinginan 68 bersama yang lebih efisien (Soemirat 2005: 14). Sedangkan reputasi berarti bagaimana peniilaian yang diterima stakeholder baik secara positif atau negatif (Gaines-Ross, 2008:6).

ProfessionalPublicRelations dituntutdapat menjadi mediator, kreator, konseptor, sekaligus komunikator dengan cara mengoptimalkan dan memberdayakan apa yang ada dan berkembang dalam masyarakat. Hasil yang ingin dicapai dalam kegiatan Public Relations pada intinya adalah good image (citra yang baik), goodwill (itikad baik), mutual understanding (saling pengertian), mutual confidence (saling mempercayai), mutual appreciation (saling menghargai), dan tolerance (toleransi). Oleh karena itu, Professional Public Relations sebagai ujung tombak informasi perusahaan menjadi sumber referensi yang harus dipercaya oleh publiknya. Apa yang disampaikannya haruslah mengandung nilai kebenaran. Sebagai pendukung di pasar ide, Professional Public Relations harus berusaha untuk memajukan cita-cita lembaga-lembaga demokratis. Baik dalam bisnis atau pemerintahan atau praktek 
non-profit, kepentingan umum dilayani hanya ketika "suara" kepentingan khusus menyajikan pandangan mereka dengan cara yang sebelumnya diinformasikan pengambilan keputusan dan memberikan kontribusi pada kesejahteraan masyarakat yang lebih besar (Fitzpatrick dan Bronstein, 2006: xi).

Ketika dalam menyampaikan informasi kepada publik, Public Relations memiliki etika kehumasan yang menjadi pedoman dalam mengambil tindakan persuasi yang strategis. Dalam menyelesaikan masalah dalam perusahaan, Professional Public Relations seringkali melakukan apa saja demi reputasi baik perusahaan, termasuk menyuarakan kepentingan perusahaan tanpa mengindahkan kepentingan publik. Oleh karena itulah, artikel ini menggambarkan Praktisi Public Relations menerapkan standar tinggi etika professional dengan didasari kejujuran dan kebenaran melalui etika advokasi sebagai kunci utama terhadap apa yang mereka lakukan, terutama ketika menangani krisis yang terjadi di perusahaan.

\section{Pembahasan}

\section{Etika}

Etika seringkali dikaitkan dengan moral. Moral merupakan wacana normatif dan imperatif yang diungkapkan dalam rangka baik atau buruk, benar atau salah yang dianggap mutlak atau tresenden dan moral wajib untuk dilakukan. Sedangkan etika sendiri dipahami sebagai refleksi dari moral tersebut, yaitu menekankan pada upaya mencari bagaimana bertindak (bukan hanya pada masalah kepatuhan pada norma). Oleh karena itu definisi etika adalah nilai-nilai, dan asas-asas moral yang di pakai sebagai pegangan umum bagi penentuan baik buruknya perilaku manusia atau benar salahnya tindakan manusia sebagai manusia (Soemirat, 2005:169). Adapun beberapa pengertian etika menurut Ruslan (2008: 31), diantaranya :

- Etika merupakan prinsip-prinsip moral yang termasuk ilmu tentang kebaikan dan sifat dari hak.

- Etika merupakan pedoman daam berperilaku, yang diakui berkaitan dengan memperhatikan bagian utama dari kegiatan manusia.

- Etika adalah ilmu watak manusia yang ideal, dan prinsip-prinsip moral sebagai individual.

- Etika merupakan ilmu mengenai suatu kewajiban.

Dari semua definisi mengenai etika tersebut, maka etika dibagi menjadi dua. Yang pertama, etika umum yaitu membahas kondisi dasar bagaimana manusia bertindak etis, dalam mengambil keputusan etis, dan teori etika serta mengacu pada prinsip moral dasar yang menjadi pegangan dalam bertindak dan tolok ukur atau pedoman untuk menilai baik buruknya suatu tindakan. Yang kedua adalah etika khusus, yaitu bagaimana mengambil keputusan dan bertindak dalam kehidupan sehari-hari pada proses dan fungsional dari suatu organisasi, atau seorang profesional untuk bertindak etis yang berlandaskan teori-teori etika dan prinsipprinsip moral dasar. Etika khusus dibagi menjadi etika individual dan etika sosial. Etika individual menyangkut kewajiban dan perilaku manusia terhadap dirinya sendiri untuk mencapai kesucian kehidupan pribadi. Sedangkan etika sosial berbicara mengenai kewajiban, sikap dan perilaku sebagai anggota masyarakat yang berkaitan dengan nilai-nilai sopan santun, tata krama dan saling menghormati, yaitu bagaimana saling berinteraksi yang menyangkut hubungan manusia denganmanusia, baik secara perorangan dan langsung, maupun secara bersama-sama atau kelompok dalam bentuk kelembagaan masyarakat dan organisasi formal lainnya. Dari sinilah etika Public Relations menjadi bagian dari etika sosial untuk menjalankan tugas dan fungsinya.

\section{Public Relations sebagai Disiplin Etis}

Aktivitas public relations menjalankan komunikasi timbal balik (two way trafic communications) antara perusahaan dengan publiknya. Oleh karena itu, Professional Public Relations tidak terlepas dari pengabdiannyademi 
kepentingan umum (it should serve the public's interest). Berkaitan dengan Kode Etik Asosiasi Perhumasan Internasional (International Public Relations Association Code of Conduct) yang menegaskan bahwa setiap Professional Public Relations tidak dibenarkan untuk mengangkat suatu konflik yang terjadi atau hal yang sengaja dipaparkan kepada publik tanpa seizin dari mereka yang berkepentingan atau bersangkutan. Sebaliknya, pihak Professional Public Relations tidak dibenarkan pula dengan sengaja untuk menutupi masalah atau krisis yang tengah terjadi di lembaga yang bersangkutan dengan cara mengelabui publik. Rosenthal et al (1989:10) dalam Irwin (1994:103) mendefinisikan krisis sebagai ancaman serius dalam struktur dasar atau nilai funamental dan norma dari sistem sosial, dimana tekanan berat dan dihadapkan pada situasi yang sangat tidak pasti, yang mengharuskan mengambil keputusan penting.

Krisis memberi kesempatan bagi orangorang tertentu untuk menjadi pahlawan, penyelamat, pemenang atau menjadi pengubah. Apabila krisis ini dapat diatasi dengan baik maka akan timbul nama besar, keharuman dan reputasi. Krisis menjadi turning point for better or worse (titik balik untuk makin baik atau makin buruk) (Gray, 1986: 27-28 dalam Kasali, 2006:222). Masa krisis merupakan momen yang menentukan. Apabila diselesaikan dengan baik maka melahirkan kemenangan dan apabila ditangani dengan buruk maka akan timbul korban. Karena menyangkut keresahan banyak publik, disinilah peran Public Relations sangat strategis dalam menyampaikan advokasi dengan benar dan jujur.

Menurut Jefkins (1998:128), kredibilitas adalah hal yang penting dan dapat membawa kesuksesan bisnis perusahaan. Public Relations adalah mengenai pengetahuan dan pemahaman dan mengarah pada niat baik dan reputasi. Kejujuran adalah kebijakan terbaik. Professional Public Relations bertanggungjawab untuk memproduksi informasi faktual, akurat dan tanpa komentar. Keterbukaan menjadi modal awal seorang Professional Public Relations dapat dipercaya oleh stakeholdernya. Ketika menghadapi situasi yang darurat misalnya konflik, pertikaian, hingga terjadi suatu krisis, maka fungsi dan tugas Professional Public Relations adalah wajib untuk menjelaskan secara jujur dan terbuka. Atas dasar inilah muncul etika advokasi. Etika advokasi muncul atas keprihatinan tentang teknik persuasi yang hanya memfokuskan pada keefektifan upaya untuk mencapai tujuan advokasi, tanpa memperhatikan prinsip-prinsip moral dasar yang mungkin dilanggar, atau orang-orang dan kepentingan yang mungkin dirugikan dalam proses persuasi tersebut.

Dalam menangani krisis, Professional Public Relations berperan sebagai penyampai keputusan atau kebijakan oleh perusahaannya (intermediator), bertindak mewakili "tokoh" untuk berhadapan kepada publik melalui media pers (komunikator), menyelenggarakan hubungan baik dengan publik (relationship), berupaya melindungi nama baik perusahaan (back up management), sebagai narasumber dan menciptakan citra baik (good news resoure and image maker), serta bekerja profesional dan bertindak secara etis sesuai dengan kode etik dan etika profesional. Dalam menjalankan perannya harus berlandaskan kejujuran, etika, dan moral yang tinggi sebagai Professional Public Relations. Prinsip moral dalam pemberian informasi yang benar dan apa adanya merupakan wujud etika advokasi. Etika biasanya sebagai panduan untuk membedakan benar dan salah, dan menentukan sifat apa yang harus dihargai. Disiplin etis dalam Public Relations di dalamnya ada nilai-nilai seperti kejujuran, keterbukaan, loyalitas, pemikiran yang adil, menghormati, integritas, dan komunikasi terus terang.

Dilema etis muncul ketika akhirnya adalah bagaimana persuasi yang dilakukan untuk memperoleh atau mempertahankan citra bagi lembaga yang diwakilinya. Di sisi lain, Professional Public Relations memiliki tanggung jawab sosial (social responsibility) terhadap pubiknya. Etika advokasi menjadi solusi dilematik diantara membela kepentingan perusahaan dan kepentingan publik. Beberapa variabel pengganggu simetris kepentingan 
perusahaan dan kepentingan publik adalah terkait dengan masalah keuangan, kedekatan dalam merespon masalah, tujuan perusahaan yang dipertaruhkan, analisis bahaya vs baik, dan lainnya (Lieber, 2003: 4).

Etika advokasi adalah pedoman yang terbaik untuk dapat menentukan fakta-fakta yang berkaitan dengan masalah dan membujuk publik untuk memahami atau setuju dengan mereka interpretasi (Pfau \& Wan, 2006) . Oleh karena itu seringkali peran Public Relations disamakan dengan seorang pengacara, di mana "persuasi memainkan peran integral". Namun, pendekatan ini kurang ketulusan karena menekankan satu sisi persuasi dan tidak memungkinkan untuk keabsahan fakta-fakta yang bertentangan muncul di luar organisasi atau dari publik lainnya. Advokasi kadang-kadang bisa sulit karena dapat membingungkan loyalitas kepada perusahaan atau membela kebenaran.

Komunikasi persuasif yang dilakukan Professional Public Relations merupakan upaya pemulihan citra dan mempertahankan citra perusahaan agar timbul kepuasan dan kepercayaan dari stakeholder. Persuasi memiliki arti sebagai prinsip dan proses yang sikap, keyakinan, dan perilaku yang terbentuk, dimodifikasi, atau memengaruhi orang lain untuk menolak perubahan (Chaiken, et al dalam Deutsch, 2000: 144). Persuasi komunikasi yang dilakukan Professional Public Relations untuk mendapatkan kesepakatan dengan publiknya yang kemudian diharapkan dapat meredam situasi krisis. Aktivitas-aktivitas yang perkembangan Public Relations sebenarnya bisa dikatakan keberadaan manusia dalam unsur memberikan informasi serta mengintegrasikan peran Professional Public Relations sehingga mendapatkan opini publik serta komunikasi sehingga terciptanya kesadaran. Pengertian bersama yang tidak ambigu adalah tujuan dari kegiatan Public Relations dalam mengatasi krisis. Dari yang sifatnya negatif seperti permusuhan, prasangka, sikap apatis, ketidaktahuan menjadi pengetahuan, rasa simpati, penerimaan dan ketertarikan.

\section{Belajar dari Kasus Adam Air vs Air Asia}

Beberapa fenomena yang sering menjadi pelanggaran yang dilakukan Professional Public Relations adalah memanipulasi data-data kepada publik atau atau memberi informasi yang tidak sesuai fakta yang sesungguhnya kepada publiknya. Hal ini dilakukan semata karena menjaga reputasi perusahaan. Pelanggaran secara moral ketika menjalankan tugas dan fungsinya ini dimungkinkan karena posisi strategis dari Public Relations sebagai pengambil keputusan strategi menangani krisis.

Misalnya adalah ketika kecelakaan pesawat Adam Air tahun 2007. Kecelakaan Adam Air 737-300 dengan nomor penerbangan KI172 dengan mengangkut 148 orang penumpang diberitakan mengalami keretakan badan pesawat pesawat di bandara Juanda, Surabaya. Media mengabarkan bahwa manajemen Adam Air tidak berterus terang mengenai keretakan badan pesawat tersebut, melainkan membantah pernyataan mengenai keretakan pesawat Adam Air 737-300. Pihak Adam Air terkesan menutupnutupi peristiwa yang terjadi. Adam Air sendiri terbukti melalui gambar yang tersebar di media telah mengecat seluruh badan pesawat menjadi warna putih dan menutup retakan dibelakang sayap pesawat menggunakan kain berwarna putig. Dari sejumlah bukti yang telah tersebar di media, Public Relations Adam Air tetap membantah mengenai keretakan pesawat yang dialami oleh pesawat Adam Air 737300, dan memilih tida memberikan komentar mengenai berita pengecatan tersebut. Hal ini mungkin menjadi tugas Professional Public Relations yang harus dilakukan, namun ini menjadi sebuah pelanggaran yang tidak etis karena telah membohongi publik.

Persepsi dari masyarakat bahwa Public Relations sebagai praktisi humas yang sering memanipulasi kebenaran itulah yang mendorong perlunya para Professional Public Relations lebih memahami kode etik profesi yang menekankan kejujuran dan kebenaran di atas segalanya. Dengan adanya kode etik, maka profesi Public Relations akan secara terbuka dapat dinilai oleh masyarakat sehingga para 
profesionalnya bisa mempertanggung jawabkan apa yang telah dikerjakannya. Keterbukaan dan transparansi informasi menjadi modal utama dalam menangani krisis. Tidak dbenarkan apabila Professional Public Relations menutupnutupi isu dan informasi "bermasalah" (to kill the information). Seharusnya isu yang sudah mencuat di permukaan, Professional Public Relations tidak berupayauntukmemutarbalikkan fakta demi kepentingan sepihak.

Etika dalam profesi kehumasan adalah suatu etika yang berfungsi sebagai penyanggah profesi Public Relations dalam menghadapi massa yang akan datang (untuk menghindari pelanggaran). Dengan adanya etika profesi ini diharapkan pergeseran nilai-nilai dan budaya serta mengeluarkan pendapat yang lebih ekstrim yang tidak sesuai dengan normanorma dan perilaku dalam hubungan dapat dicegah. Idealnya, etika Public Relations harus bersendikan pada nilai-nilai kejujuran, akurasi, integritas, dan kebenaran. Sayangnya, tuntutan dari klien atau perusahaan ada kalanya memaksa tugas Public Relations untuk melakukan manipulasi, penipuan, bahkan kebohongan publik.

Dalam kasus Adam Air di atas, Public Relations telah melanggar beberapa kode etik Public Relations, diantaranya :

\section{IPRA (International Public Relation} Association) Code of Conduct.

IPRA Code of Conduct butir C menyebutkan bahwa lembaga kehumasan tidak diperkenankan untuk menyebarkan secara sengaja informasi yang palsu atau menyesatkan". Public Relations Adam Air telah menyebarluaskan informasi palsu dengan menutupi fakta bahwa badan pesawat telah retak dan menutupi barang bukti dengan manipulasi data.

\section{Kode Etik Kehumasan (KEKI).}

KEKI pasal III menyebutkan bahwa anggota perhumasan tidak boleh menyebarkan informasi yang tidak benar atau yang menyesatkan sehingga dapat menodai profesi kehumasan.
Kasus Adam Air ini juga melanggar etika advokasi. Dalam mempersuasi publik, Public Relations hanya memfokuskan pada keefektifan upaya untuk mencapai tujuan advokasi, tanpa memperhatikan prinsip-prinsip moral dasar yang mungkin dilanggar, atau orang-orang dan kepentingan yang mungkin dirugikan dalam proses persuasi tersebut. Tujuan dari manipulasi data Adam Air dalam mempersuasi publiknya agar tercipta citra perusahaan yang baik. Menurut J. Baudrillard (1981:17) dalam Haryatmoko (2007: 33) menyatakan bahwa pencitraan mendiskualifikasi kategori kebenaran sehingga tidak bisa lagi dibedakan antara realitas, representasi, simulasi, kepalsuan, dan hiperrealitas. J. Baudrillard menjelaskan empat fase citra: pertama, representasi dimana citra merupakan cermin suatu realitas; kedua, ideologi dimana citra menyembunyikan dan memberi gambar yang salah akan realitas; ketiga, citra menyembunyikan bahwa tidak ada realitas dan citra bermain menjadi penampakannya; keempat, citra tidak ada hubungan sama sekali dengan realitas apa pun, lalu ia hanya menjadi yang menyerupai dirinya.

Di sisi lain, upaya Public Relations untuk mengecat badan pesawat tidak dianggap sebagai sesuatu yang tidak etis. Hal ini didasarkan pada prinsip utilititarianisme. Utilitarianisme menekankan pada asas manfaat dari konsekuensi. Dalamutilitarianismekeputusan etis didefinisikan sebagai sesuatu yang memaksimalkan konsekuensi positif dan meminimalkan hasil negatif. Dalam utilitarian pendekatan terhadap etika, dengan berat keputusan potensial dan konsekuensi kemungkinan mereka adalah analisis etis digunakan untuk menentukan benar atau salah. Manajemen Adam Air melalui Public Relationsnya menyampaikan bahwa pengecatan badan pesawat tidak menghilangkan barang bukti namun hanya menghindari trauma masyarakat. Atas dasar asas manfaat ini, persuasi sebagai bentuk advokasi yang dilakukan oleh Professional Public Relations dibolehkan menurut prinsip utilitarianisme.

Penanganan krisis kecelakaan pesawat Adam Air yang berujung pada perdebatan 
kode etik oleh Public Relationsnya, bertolak belakang ketika pesawat Air Asia mengalami hilang kontak. Kasusnya adalah Pesawat AirAsia dengan nomor penerbangan QZ 8501 dikabarkan hilang kontak pada hari Minggu 28/12/2014 pagi. Pesawat jenis Airbus 320-200 tersebut terbang dari Surabaya dan berencana menuju Singapura. Pesawat ini lepas landas dari Bandara Udara Internasional Juanda pada pukul 05:35 Waktu Indonesia Barat (UTC+7) dan dijadwalkan untuk mendarat di Singapura pada pukul 08:30 WSS (UTC+8). Pesawat kehilangan kontak dengan pengatur lalu lintas udara pada pukul 07:00 waktu setempat saat sedang terbang di atas laut Jawa. Pesawat yang mengangkut 162 penumpang dan awak tersebut dinyatakan hilang dan di hari ketiga pencarian dipastikan pesawat jatuh ke laut Jawa.

AirAsia dinilai tanggap dan responsif dalam menanggapi musibah tersebut. Salah satunya ditunjukkan melalui respon positif masyarakat terhadap postingan CEO AirAsia karena pada saat diketahui pesawat hilang kontak, CEO Air Asia Tony Fernandes langsung mengucapkan bela sungkawa-nya melalui akun twitter-nya@tonyfernandes “My heart is filled with sadness for all the families involved in $Q Z$ 8501. On behalf of AirAsia my condolences to all. Words cannot express how sorry I am." yang langsung mendapatkan respon positif dari khalayak. Selain itu, sejak resmi dinyatakan hilang pada 28 Desember, Tony Fernandes langsung terbang ke Surabaya guna menjumpai sekaligus berkomunikasi langsung dengan keluarga penumpang serta keluarga para crew pesawat AirAsia QZ8501.

Upaya mengatasi krisis yang dilakukan oleh tim Public Relations berpegang pada etika advokasi. Ungkapan belasungkawa sebagai tanda simpati terhadap korban. Responsif yang ditunjukkan langsung oleh CEO sebagai pucuk pimpinan perusahaan membuat publik percaya bahwa perusahaan betul-betul memiliki tanggung jawab dan rasa hormat serius menangani kasus kecelakaan ini. Informasi perkembangan pencarian korban juga disampaikan melalui media yang selama ini berhubungan baik dengan pihak perusahaan. Hal ini sesuai dengan apa yang diberitakan di majalah Mix: jika dibandingkan dengan maskapai penerbangan low cost carrier lainnya di Tanah Air, tim Public Relations Air Asia Indonesia tergolong lebih akrab, jauh lebih terbuka dan transparan dengan media (http:// mix.co.id/public-relations/mengintip-mediarelationship-strategy-dari-pr-airasia-ketikamengelola-krisis/).

Apa yang dilakukan Air Asia sesuai dengan prinsip dasar etika advokasi yaitu Pertama, hubungan masyarakat profesional harus hati-hati mempertimbangkan resikonya dan manfaat dari tindakan yang dilakukan. Kedua, memastikan bahwa dirinya menghormati semua orang. Ketiga, Professional Public Relations harus melihat bahwa semua penghargaan dan kesulitan sama-sama dialokasikan. Prinsipprinsip ini merupakan dasar bagi teori advokasi bertanggung jawab. Secara keseluruhan, prinsip dasar teori etika advokasi oleh Fitzpatrick \& Gauthier menunjukkan yang ideal dari Professional Public Relations mampu melayani kepentingan klien dan secara bersamaan juga melayani kepentingan masyarakat luas.

Tim Public Relations Air Asia mengatasi permasalahan krisis pasca kecelakaan pesawat dengan baik dan sesuai dengan etika advokasi. Menurut Ulmer (2007: 170) ada tiga isu etis dalam menangani situasi krisis yaitu dengan menonjolkan rasa tanggung jawab dan akuntabilitas, akses informasi yang mudah, dan rasa kepedulian terhadap publiknya yang tinggi. Ketiga isu etis ini teah berhasil diterapkan oleh Public Relations Air Asia yang diwakili langsung oleh CEO sebagai top manajemen.

\section{Model Etika dalam Mengatasi Krisis}

Di dalam menjalankan peran dan fungsinya, Professional Public Relations memiliki beberapa model etika yang dapat diterapkan dalam mempersuasi publik untuk mengatasi krisis reputasi perusahaan, diantaranya (Lieber, 2003: 7-9) : (1). Attorney Adversary Model, yaitu dimana tim Public Relations melakukan fungsi persuasif yang mirip dengan seorang 
pengacara. (Barney and Black's, 1994). Model pengacara-musuh beroperasi di bawah asumsi bahwa jika pesan bersaing dan sudut pandang cukup terwakili, kebenaran akan pasti muncul (Fitzpatrick \& Gauthier, 2001). Demikian pula, dalam opini publik yang terbentuk atas simpati yang ditunjukkan secara langsung diharapkan membendung opini negatif menyebar di masyarakat. Setelah mempertimbangkan informasi yang diberikan oleh pihak tim Public Relations maka diharapkan terbentuk opini cerdas masyarakat mendukung langkah mengatasi krisis yang terjadi. (2). Two-way Symmetrical Model, dimana Public Relations sebagai forum diskusi di mana berbagai individu, pendapat dan nilai-nilai datang bersama-sama, umumnya akan memiliki kesimpulan yang berbeda (Fitzpatrick \& Gauthier, 2002). Model ini mendefinisikan etika sebagai proses Public Relations daripada hasil. Forum ini, mirip dengan fungsi wacana Attorney Adversary Model, yaitu mematuhi aturan etika tertentu dan standar dengan tujuan hasil etis. Professional Public Relations, melakukan tugasnya mirip dengan menentang pengacara yang membela klien mereka. Professional Public Relations bekerja sebagai perantara kepentingan publik untuk disampaikan ke perusahaan untuk mencapai kesepakatan etis sebagai tujuan akhirnya. (3). Social Responsibility Model, yaitu model tanggung jawab sosial dari Professional Public Relations merupakan pola normatif operasi pers, juga berfungsi sebagai dasar untuk konsep jurnalisme sipil. Model ini menggambarkan bahwa Professional Public Relations melakukan kegiatan kampanye untuk melayani kepentingan publik yang lebih luas dan komunal yang baik (Baker, 2002 dalam Wilkins and Christians, 2009: 118). Model tanggung jawab sosial mirip dengan model komunitarianisme, yang kemudian meluas menjadi model tanggung jawab sosial untuk memasukkan tugas tambahan sebagai pihak yang mendukung kepentingan masyarakat dan mempromosikan nilai-nilai komunal keadilan, demokrasi, dan kebenaran. (4). Partisan versus Mutual Values Model, yaitu Professional Public Relations sebagai persimpangan antara kepentingan perusahaan dan kepentingan publik. Public Relations adalah kepanjangan tangan dari perusahaan yang memiliki kewajiban untuk melindungi reputasi perusahaan. Sebuah keseimbangan antara kewajiban untuk menjalankan profesi terhadap perusahaan dan "prinsip mutualitas" untuk kepentingan publik sehingga menjadi proses strategi komunikasi yang bertanggung jawab. (5). Professional Responsibility Model, yaitu model yang mengacu pada tanggung jawab profesi sebagai Professional Public Relations. Dalam menjalankan tugasnya, Professional Public Relations mengesampingkan kepentingan fungsi komunikator melainkan sebagai melayani dalam "profesional" peran. Empat kriteria dalam Professional Responsibility Model adalah: a) keanggotaan dalam sebuah organisasi profesional, b) keahlian khusus, c) orientasi terhadap pelayanan, dan d) otonomi dalam operasi.

Model etika dalam mengatasi krisis dapat digunakan untuk memudahkan Professional Public Relations dalam mengambil kebijakan strategi pengelolaan krisis. Kepentingan mana yang lebih diunggulkan, atau bahkan bisa mengakomodasi atau menyeimbangkan kepentingan perusahaan dan kepentngan publik dalam mempersuasi publik untuk mendapatkan kepercayaan kembali kepada perusahaan.

\section{Moralitas Public Relations dalam Manaje- men Krisis}

Apa yang dilakukan oleh Public Relations dalam mengatasi krisis adalah persoalan etis. Baik atau tidaknya, benar atau salahnya melakukan strategi manajemen krisis tersebut sesuai dengan rasa tanggung jawab atau tidak. Tindakan etis Professional Public Relations sesuai dengan pedoman dalam berperilaku atau bertindak sebagai profesional dalam pengambilan keputusan, dan prosedur apa yang diakukannya secara obyektif, serta dapat dipertanggungjawabkan. Public Relations berpegang pada kode etik profesi (code of profession) dan kode perilaku (code of conduct). Seperti tertulis dalam Code of Professional 
Standards of the Public Relations Society of America, Professional Public Relations harus bertindak jujur dan dapat dipercaya, dalam segala tindakan untuk kepentingan publik. Sedangkan etika advokasi adalah upaya untuk menemukan cara yang berguna untuk konsep, mengontekstualisasikan, dan menerapkan prinsip etika untuk isu advokasi dan persuasi.

Etika advokasi dalam mempersuasi publik dalam kaitannya dengan manajemen krisis meliputi komunikasi persuasif harus benar-benar menghindari atau meminimalisasi resiko akibat komunikasi yang dilakukan, rasa menghormati orang dan memperlakukan mereka dengan martabat yang tepat, dan mengkomunikasikan "manfaat dan beban "dari suatu tindakan atau kebijakan yang adil. Professional Public Relations dalam menjalankan pekerjaanya harus dapat membedakan secara etis mana yang boleh dilakukan dan mana yang tidak boleh dilakukan. Secara umum terdapat beberapa prinsip yang dijalankan oleh Professional Public Relations (Keraf, 1993: 50 dalam Ruslan, 2008: 53), diantaranya : (1). Tanggung jawab, yaitu setiap orang penyandang profesi tertentu harus memiliki rasa tanggung jawab terhadap profesi, baik tanggung jawab terhadap fungsinya ataupun tanggung jawab terhadap dampak atau akibat dari tindakan profesinya. (2). Kebebasan, yaitu profesional memiliki kebebasan dalam menjalankan profesinya tanpa merasa takut atau ragu-ragu, tetapi tetap memiliki komitmen dan bertanggung jawab dalam batas-atas aturan main yang telah ditentukan oleh kode etik sebagai standard perilaku profesional. (3). Kejujuran, yaitu rasa jujur dan setia serta merasa terhormat pada profesi yang disandangnya, mengakui akan kelemahannya dan tidak menyombongkan diri, serta berupaya terus untuk mengembangkan diri daam mencapai kesempurnaan bidang pelatihan dan profesional melalui pendidikan, pelatihan, dan pengalaman. Disamping itu tidak akan melacurkan profesinya untuk tujuan yang tidak dapat dipertanggungjawabkan, demi tujuan materi semata atau kepentingan sepihak. (4). Keadilan, yaitu setiap profesional memiliki kewajiban dan tidak dibenarkan melakukan pelanggaran terhadap hak atau mengganggu milik orang lain, lembaga atau organisasi hingga mencemarkan nama baik bangsa dan negara. Selain itu juga harus menghargai hakhak, menjaga kehrmatan nama baik, martabat dan milik bagi pihak lain agar tercipta saling menghormati dan keadilan secara obyektif dalam kehidupan masyarakat. (5). Otonomi, yaitu profesional memiliki kebebasan secara otonom dalam menjalankan profesinya sesuai dengan keahlian, pengetahuan dan kemampuannya. Apa pun yang dilakukannya merupakan konsekuensi dari tanggung jawab profesi, kebebasan otonom merupakan hak dan kewajiban yang dimiliki bagi setiap porofesional.

Dengan berpegang teguh pada prinsip profesi Public Relations, maka Professional Public Relations dalam mempersuasi publiknya haruslah memiliki kualifikasi kemampuan antara lain (Ruslan, 2008: 52-53):

\section{Kemampuan untuk kesadaran etis} (ethical sensibility)

Kemampuan ini merupakan landasan kesadaran yang utama, sensitifitas bersifat obyektif bukan subjektif.

\section{Kemampuan untuk berpikir secara etis (ethical reasoning)}

Kemampuan berwawasan dan berpikir secara etis dan mempertimbangan tindakan profesi atau mengambil keputusan harus berdasarkan pertimbangan rasional, obyektif, dan penuh integritas pribadi serta tanggung jawab yang tinggi.

\section{Kemampuan untuk berperilaku secara etis (ethical conduct)}

Kemampuan berperilaku sikap, etika moral dan tata krama ang baik dalam bergaul atau berhubungan dengan pihak lain.

\section{Kemampuan untuk kepemimpinan yang etis (ethical leadership)}

Kemampuan untuk memimpin secara etis untuk dapat mengayomi, membimbing dan membina pihak lain yang dibimbingnya.

$$
\text { Inti dari aturan Public Relations }
$$


Society dan International Association of Business Communication adalah kejujuran dan keadilan yang harus ada di hati setiap Professional Public Relations. Aturan-aturan ini menekankan pentingnya bagi para anggota untuk mempromosikan dan menjaga standar tinggi untuk pelayanan publik dan pelaksanaan etika. Seiring berjalannya waktu nilai standar etika akan berubah sesuai perubahan yang terjadi di tengah masyarakat. Salah satu manifestasi dari tingginya perhatian terhadap etika adalah berkembangnya pembuatan codes of conduct internal perusahaan yang berisi tentang kode etik, standar pelaksanaan serta peraturan yang merupakan representasi dari nilai perusahaan (corporate value). Codes of Conduct perusahaan diharapkan dapat menjadi mekanisme meningkatkan kepatuhan karyawan. Alasan yang mendasari perusahaan mengadopsi aturan-aturan tersebut adalah sebagai berikut:

Meningkatkan kepercayaan publik

Skandal yang berkaitan dengan kerahasiaan informasi perusahaan, penyalahgunaan aset, penyuapan, korupsi, dan perselingkuhan membuat banyak perusahaan merespon hal ini dengan menetapkan kode etik tertulis.

Menyesuaikan aturan pemerintah

Semakin ketatnya peraturan pemerintah terhadap dunia bisnis akan mengubah peta persaingan sehingga setiap perusahaan harus melakukan penyesuaian.

\section{Meningkatkan kegiatan operasional internal}

Apabila perusahan semakin besar dan terdesentralisasi, maka manajemen membutuhkan standar pelaksanaan untuk memastikan bahwa karyawan memenuhi apa yang diinginkan konsumen dengan perilaku yang legal dan etis.

\section{Untuk merespon terhadap pelanggaran hukum}

Seringkali, ketika sebuah perusahaan melakukan perilaku yang tidak etis, hal tersebut tertangkap oleh kode etik perusahaan sendiri.

\section{Penutup}

\section{Simpulan}

Dalam menangani krisis perusahaan, Professional Public Relations dituntut untuk dapat menyeimbangkan kepentingan perusahaan dan kepentingan publiknya. Etika advokasi menjadi solusi dilematik diantara membela kepentingan perusahaan dan kepentingan publik. Disiplin etis dalam Public Relations memiliki nilai-nilai seperti kejujuran, keterbukaan, loyalitas, pemikiran yang adil, menghormati, integritas, dan komunikasi terus terang. Hal ini tercermin dari kasus kecelakaan pesawat Adam Air yang sebagian berpendapat upaya penanganan krisis dengan mengecat badan pesawat dianggap menyalahi kode etik sedangkan paham utilitarianisme menganggap bahwa hal itu diperbolehkan karena membawa asas manfaat yaitu mengurangi rasa trauma masayarakat. Upaya etis dalam menangani krisis lainnya adalah kasus kecelakaan Air Asia yang responsif, terbuka, jujur, dan tanggung jawab sehingga kepentingan perusahaan dan kepentingan publik dapat terakomodasi dengan baik. Model-model etika dalam mengatasi krisis meliputi Attorney Adversary Model, Twoway Symmetrical Model, Social Responsibility Model, Partisan versus Mutual Values Model, dan Professional Responsibility Model. Sedangkan tindakan etis Professional Public Relations dalam manajemen krisis berpegang pada kode etik profesi (code of profession) dan kode perilaku (code of conduct) agar dapat berperilaku atau bertindak sebagai profesional dalam pengambilan keputusan, dan prosedur apa yang dilakukannya secara obyektif, serta dapat dipertanggungjawabkan.

\section{Saran}

Professional Public Relations sebaiknya menggunakan strategi yang mengandung nilai kebenaran berdasarkan pada kode etik profesi dan kode perilaku ketika perusahaan mengalami krisis reputasi perusahaan. Dalam menyeimbangkan kepentingan perusahaan dan kepentingan publik, Professional Public Relations berprinsip pada etika advokasi yang 
tidak hanya memfokuskan pada keefektifan upaya untuk mencapai tujuan advokasi, tanpa memperhatikan prinsip-prinsip moral dasar yang mungkin dilanggar, atau orang-orang dan kepentingan publik yang mungkin dirugikan dalam proses persuasi tersebut. Dalam setiap menjalankan tugasnya, Professional Public Relations diwajibkan memiliki karakteristik yang jujur, terbuka, informatif, adil, dan bertanggung jawab atas segala aktualisasi pengelolaan krisis.

\section{Daftar Pustaka}

Deutsch,Morton. (2000). The Handbook of Conflict Resolution: Theory and Practise. San Fransisco: Jossey-Bass Publishers.

Gaines-Ross, Leslie. (2008). Corporate Reputation: 12 Steps to Safeguarding and Recovering Reputation. Canada: John Willy \& Sons, Inc.

Haryatmoko. (2007). Etika Komunikasi. Yogyakarta: Penerbit Kanisius.

Irwin, Harry and Elizabeth More. (1994). Managing Corporate Communication. Australia: Allen\&Unwin Pty Ltd.

Jefkins, Frank. (1998). Framework Public Relations Fifth Edition. England: Pearson Education Limited.

Kasali, Rhenald. (2006). Manajemen Public Relations: Konsep dan Aplikasinya di Indonesia. Jakarta: PT Pustaka Utama Grafiti.

Ruslan, Rosady. (2008). Etika Kehumasan: Konsepsi dan Aplikasinya. Jakarta: PT. Raja Grafindo Persada.

Soemirat, Soleh dan Elvinaro Ardianto. (2005). Dasar-Dasar Public Relations.
Bandung: Remaja Rosdakarya.

Ulmer, Robert R, Timothy L. Sellnow and Matthew W. Seeger. (2007). Effective Crisis Communication: Moving From Crisis to Opportunity. USA: Sage Publications Inc.

Wilkins, Lee and Christians, Clifford G. (2009). The Handbook of Mass Media Ethics. New York and London: Routledge.

\section{Jurnal dan Penelitian}

Fitzpatrick, Kathy and Gauthier, Candace. (2001). Toward a Professional Responsibility Theory of Public Relations Ethics. Journal of Mass Media Ethics 16: 193-212.

Lieber, Paul Stuart. (2003). Ethics In Public Relations: Gauging Ethical DecisionMaking Patterns Of Public Relations Practitioners. Thesis. USA: Syracuse University

Pfau, M. and Wan, H. (2006) Persuasion: An intrinsic function in public relations, Botan, C. H. and Hazleton, V. (2006) (eds) Public relations theory II, Lawrence Erlbaum Associates, Mahweh, NJ hal 101-136.

\section{Internet}

http://www.bakrie.ac.id/en/news/594mengungkap-rahasia-manajemenkrisis-maskapai-airasia-dibalik-tragedipesawat-qz8501 diakses pada hari Rabu tanggal 18 November 2015 jam 15.10WIB.

http://www.antaranews.com/print/53906/ adam-air-cat-badan-pesawat-yangnaas diakses pada hari Rabu tanggal 18 November 2015 ja 